\title{
CDISC SEND Death Diagnosis Test Code Terminology
}

National Cancer Institute

\section{Source}

National Cancer Institute. CDISC SEND Death Diagnosis Test Code Terminology. NCI

Thesaurus. Code C89966.

The terminology that includes concepts relevant to the Clinical Data Interchange Standards Consortium (CDISC) Standard for the Exchange of Non-clinical Data (SEND) death diagnosis test short names. 